\title{
TINGKAT PRODUKTIVITAS PADA AGLOMERASI INDUSTRI (STUDI KASUS : SENTRA INDUSTRI MEBEL TUNJUNGSEKAR)
}

\author{
Dinar Amelia Ashary ${ }^{* 1}$, Wawargita Permata Wijayanti ${ }^{2}$, Dian Dinanti $^{3}$ \\ Jurusan Perencanaan Wilayah dan Kota Fakultas Teknik Universitas Brawijaya ${ }^{123}$ \\ Jalan Mayjen Haryono 167 Malang 65145 - Telp (0341) 567886 \\ e-mail*: ameliadinar31@gmail.com
}

\begin{abstract}
ABSTRAK
Industri Kecil dan Menengah (IKM) mampu menyerap tenaga kerja lebih dari $60 \%$ dari sektor industri, memiliki ketahanan akan kiris ekonomi dan juga berperan dalam ekonomi lokal. Namun, permasalahan yang sering dihadapi oleh IKM adalah produktivitas yang masih fluktuatif sehingga IKM juga rawan untuk mendapatakan keuntungan yang tidak banyak bahkan merugi seperti yang dialami pada Sentra Industri Mebel Tunjungsekar di Kota Malang. Padahal sentra adalah salah satu bentuk aglomerasi industri yang memunculkan manfaat ekonomi berupa limpahan tenaga kerja, kerja sama suplier khusus, terjadinya transfer pengetahuan dan teknologi, serta kerja sama pemasaran. Produktivitas sentra industri mebel ini mengalami rintangan terutama pada persediaan bahan baku kayu, tenaga kerja yang masih mengandalkan kekerabatan, serta belum adanya kerja sama dalam jaringan yang kuat. Maka penelitian ini bertujuan untuk menentukan tingkat produktivitas setiap unit industri dalam satu sentra. Data yang digunakan adalah nilai biaya, nilai modal, dan nilai pendapatan masing-masing industri pada tahun 2019. Hasil analisis menunjukkan tingkat produktivitas ke-30 industri mebel rata-rata sebesar 1,31 dengan nilai terendah 1,14 dan tertinggi sebesar 1,58. Meskipun memiliki nilai >1,0, tetapi semua industri belum mencapai nilai produktivitas yang ideal dimana selisih antara nilai minimal tersebut hanya 0,14 - 0,58. Terdapat 15 industri yang berada di bawah rata-rata nilai produktivitas dikarenakan tingginya biaya bahan baku dan modal tidak diimbangi dengan tingginya jumlah pesanan produk mebel. Hal ini menunjukkan bahwa ke-15 industri tersebut tidak berada dalam kondisi yang prima untuk dapat mempertahankan industrinya di masa mendatang.
\end{abstract}

Kata Kunci : produktivitas industri, aglomerasi, industri kecil dan menengah.

\section{ABSTRACT}

Small and medium industries (IKM) are very beneficial for absorbing more than $60 \%$ of workers, having better economic resilience, and increasing local economic. However, they face a serious problem related to the economic productivity which the fluctuative productivity makes the industries can not be able to get much profit, as experienced in Sentra Industri Mebel Tunjungsekar in Malang City. This industrial agglomeration eventually gives economic benefits in the form of an abundance of labor, special supplier cooperation, knowledge and technology transfer, and marketing cooperation. In contrary, these industries face some problems, such supply of wood raw materials, workers who still rely on kinship, and the less cooperation and network. This research aims to determine the productivity level of each industry in the Sentra Industri Mebel Tunjungsekar. We used several values: cost, capital, and income of each industry in year 2019. The result shows that an average productivity level of the 30 furniture industries is 1.31 with the lowest value of 1.14 and the highest of 1.58 . These results indicate that all industries have productivity not far above 1.0 so that this condition has not yet reached the ideal condition. There are 15 industries that are below the average value of productivity due to the high cost of raw materials and capital that are not in accordance with the number of orders for furniture products. This shows that the 15 industries are not in a prime condition to be able to maintain their industry in the future.

Keywords: industrial productivity, agglomeration, industri kecil dan menengah.

\section{LATAR BELAKANG}

Industri pengolahan non migas menjadi salah satu pilar perekonomian masyarakat Indonesia. Dalam kurun waktu tahun 2015 - 2019, jumlah industri pengolahan non migas rata-rata meningkat sebesar 4,7\% serta memberikan kontribusi terbesar pada Produk Domestik Bruto Nasional dengan rata-rata kontribusi sebesar 20\% (Laporan Kinerja Kemenperin, 2019). Industri pengolahan ini dibagi menjadi Industri Besar dan Menengah (IBS) serta Industri Kecil dan Menengah (IKM). IKM adalah sebuah usaha yang memproduksi berbagai jenis produk yang diperlukan oleh berbagai jenis makhluk hidup seperti manusia, binatang, dan tumbuhan. Perbedaan (usaha kecil dan menengah) UKM dengan IKM, UKM merupakan jenis usaha yang bertujuan menjual kembali barang yang diproduksi oleh IKM, seperti misalnya toko 
kelontong, hingga warung-warung di kita, (Permen Perindustrian No. 64 Tahun 2016).

Industri kecil adalah industri berskala kecil, baik dalam ukuran modal, jumlah produksi maupun tenaga kerjanya serta hubungan antara keterampilan teknis dan keahlian dalam pengelolaan usaha industri kecil ini dengan pendidikan formal yang dimiliki para pekerjanya umumnya lemah (Indriartiningtias, dkk, 2017).

Jumlah IKM hingga tahun 2020 sekitar 4,4 juta unit, sehingga peran IKM juga sangat penting dalam penyerapan tenaga kerja dari total penyerapan tenaga kerja pada sektor industri, lebih dari $60 \%$ dilakukan pada sektor IKM, (Badan Pusat Statistik, 2019). Sektor IKM ini juga usaha yang memiliki ketahanan akan kiris ekonomi, hal ini dibuktikan ketika terjadi krisis pada tahun 1998, jumlah IKM mampu bertahan bahkan semakin meningkat setelah terjadinya krisis. Industri pengolahan kayu merupakan salah satu industri yang berkembang pesat dan menjadi salah satu komoditi ekspor unggulan dalam sektor kehutanan, namun memiliki permasalahan karena kelangkaan bahan baku yang berkualitas tinggi (Suryandari, Elvida. Y., 2008).

Agar industri kecil memiliki kemampuan untuk terus berkompetisi dapat dikembangkan dengan "stratgei khusus" yaitu salah satunya adalah melalui pendekatan sentra industri (Djamhari, 2006). Sentra industri adalah salah satu bentuk dari aglomerasi industri. Aglomerasi terbentuk karena adanya perusahaan-perusahaan kecil yang saling terkait membentuk konsentrasi spasial dengan ditandai oleh membesarnya skala ekonomi maupun membesarnya lokasi (Kuncoro, 2002). Manfaat yang hadir ketika suatu industri beraglomerasi, seperti adanya limpahan tenaga kerja, kerja sama suplier khusus, pertukaran informasi dan teknologi serta kerja sama dalam pemasaran, (Felzensztein et al, 2010).

IKM di Kota Malang merupakan bagian yang tidak terpisahkan dalam aktivitas ekonomi masyarakatnya, industri pengolahan di Kota Malang sebesar $90 \%$ adalah industri kecil dan menengah serta telah memiliki tujuh sentra industri yang ada yaitu sentra tempe dan kripik tempe Sanan, sentra keramik Dinoyo, sentra gerabah dan sanitair Karangbesuki, sentra rotan Balearjosari, sentra emping jagung Pandanwangi serta sentra mebel Tunjungsekar (Kota Malang dalam Angka, 2020). Dalam Rencana Tata Ruang Wilayah (RTRW) Kota Malang tahun 2010-2030 sentra industri mebel di Tunjungsekar ditetapkan menjadi kawasan strategis ekonomi, dimana keberadaan kawasan strategis ekonomi akan didukung dengan sarana dan prasarana transportasi serta jaringan utilitas yang baik.
Sentra industri mebel di Tunjungsekar merupakan industri kecil terbanyak kedua setelah industri tempe kedelai (Fatmawati, Aisyah, 2008).

Sentra industri mebel Tunjungsekar ini berdiri sejak 1950-an hingga saat ini, gejala pengelompokkan industri kecil di Tunjungsekar ini terjadi secara spontan, namun sentra industri mebel ini belum ditunjang dengan dukungan kelembagaan yang baik, melakukan pemasaran hasil produk secara mandiri serta belum ada jaringan pemasaran yang kuat (Fatmawati, Aisyah, 2008). Masalah dalam bahan baku utama (kayu) juga terus mengalami kelangkaan, sehingga harganya yang cenderung semakin tinggi, kenaikan bahan baku ini berdampak pada penurunan pemesanan dikarenakan harga mebel yang semakin mahal. Selain itu juga terdapat permasalahan terhadap tenaga kerja yang masih mengandalkan kekerabatan. Apabila output dan input mengalami penurunan, dimana penurunan output lebih besar dari pada input maka produktivitas industri juga mengalami penurunan (Fitri \& Sari, 2015). Selain itu, bahan baku juga berpengaruh positif terhadap produksi, semakin langkanya ketersediaan bahan baku maka semakin terbatas pula output yang dihasilkan, sehingga produktivitas industri juga mengalami naik turun (Prianata, 2014).

Hal tersebut juga sesuai dnegan hasil penelitian sebelumnya, dimana faktor yang berpengaruh positif dan signifikan terhadap perkembangan usaha kecil adalah sistem kemitraan. Oleh karena itu, disarankan agar usaha kecil khususnya sektor industri pengolahan yang berada di kota Malang berinisiatif untuk meningkatkan kemitraan, baik kemitraan dengan pemasok, pemerintah, perguruan tinggi, lembaga inkubator, lembaga keuangan, usaha besarmaupun usaha kecil sejenis (sentra), (Cahyanti M, dan Anjaningrum.W, 2017).

Berdasarkan uraian di atas, maka mengkaji tingkat produktivitas pada sentra industri mebel di Tunjungsekar penting dilakukan untuk mengetahui tingkat produktivitas pada industri yang beraglomerasi.

\section{METODE PENELITIAN}

\section{Lokasi Penelitian}

Penelitian ini dilakukan pada Kelurahan Tunjungsekar, Kecamatan Lowokwaru, Kota Malang. Sentra industri mebel ini berada di Kampung Tunjungsekar atau di sepanjang jalan Ikan Piranha Atas sebanyak 30 unit industri mebel 
yang tergabung dalam paguyuban Sido Rukun. Luasan wilayah penelitian sekitar 5 ha.

\section{Populasi dan Waktu Penelitian}

Responden penelitian merupakan seluruh unit industri mebel di Tunjunsgekar yang tergabung dalam paguyuban Sido Rukun (30 unit). Waktu wawancara pada responden dilakukan pada tahun 2020 dengan data yang didapatkan merupakan data akumulasi dalam 1 tahun yaitu di taun 2019.

\section{Teknik Pengumpulan Data}

Teknik pengumpulan data pada penelitian ini yaitu pengumpulan data primer dilakukan melalui observasi dan wawancara pada 30 unit industri mebel di Tunjungsekar, selain itu juga melakukan wawancara dengan ketua paguyuban dan Dinas Perindustrian. Key person ini dipilih karena paling mengetahui kondisi sentra industri dan memegang data-data yang mendukung penelitian. Pengumpulan data sekunder melalui instansi terkait seperti BPS (Badan Pusat Statistik) serta Dinas Perindustrian dan Perdagangan Kota Malang.

\section{Teknik Analisis Data}

Dalam penelitian ini menggunakan analisis statistik deskriptif untuk mendapatkan tingkat produktivitas industri yang dijelaskan sebagai berikut.

\section{Perhitungan Nilai Input dan Output}

Klasifikasi nilai input dan output industri digunakan untuk melihat kecenderungan kondisi yang terjadi di Sentra Industri Mebel Tunjungsekar. Klasifikasi ini menggunakan analisis deskriptif yaitu perhitungan distribusi frekuensi. Distribusi frekuensi yaitu tabel yang disusun berdasarkan kelas-kelas atau kategori serta sekaligaus menetapkan bilangan yang menjadi anggotanya tiap kelas atau kategori dalam frekuensi. Penentuan banyak kelas dapat menggunakan rumus sturges berikut :

$$
k=1+3,3 \log n
$$

Keterangan:

$\mathrm{k}$ : jumlah kelas interval

$\mathrm{n}$ : jumlah data observasi

Tujuan pengelmpokkan data ke dalam distribusi frekuensi yaitu:

a. Memudahkan penyajian data, mudah dipahami dan dibaca sebagai infromasi b. Memudahkan menganalisis atau menghitung data, membuat tabel dan grafik

\section{Perhitungan Produktivitas}

Pada usaha industri kayu terdapat beberapa faktor input yang mempengaruhi produksi (output) yaitu modal, bahan baku dan tenaga kerja (Prawirosentono, 2000). Pengukuran produktivitas menggunakan rasio output dibagi input dapat menggunakan satuan fisik dari output dan input (ukuran berat, panjang dan lainnya) atau satuan moneter (dollar, rupiah dll). Pada penelitian ini menggunakan satuan moneter. Produktivitas Total (Total Productivity) menunjukkan produktivitas dari semua faktor yang digunakan untuk menghasilkan output. Faktor tersebut dapat berupa bahan mentah tenaga kerja, energi, peralatan produksi dan lain-lain.

Rumus perhitungan produktivitas menurut Blocer, 2019 :

Produktivitas Total $=\frac{\text { total output }(\text { pendapatan })}{\text { total input }(\text { pengeluaran })}$

Karakteristik perhitungan produktivitas total antara lain:

a. Nilai penjualan output adalah nilai penualan hasil produksi yang dihasilkan dalam jangka waktu tertentu.

b. Biaya total dikelompokkan menjadi dua, yaitu biaya tetap dan biaya variabel. Biaya tetap berupa kewajiban yang harus dibayar per satuan waktu tertentu dan besarnya tidak bergantung terhadap jumlah produk yang dihasilkan, contohnya penyusutan modal. Modal ialah segala sumber daya produksi yang tahan lama, yang dapat digunakan sebagai input produksi dalam proses produksi berikutnya. Biaya variabel ialah kewajiban yang harus dibayar pada waktu tertentu dan tergantung dari tingkat produksinya. Contohnya biaya variabel yaitu biaya bahan baku dan upah buruh.

\section{Klasifikasi Nilai Produktivitas}

Nilai produktivitas diklasifikasikan menggunakan Malmquist Productivity Index yaitu indeks yang digunakan untuk membandingkan antara input dan output dalam konsep produksi, pertama kali dikenalkan oleh Malmquist pada tahun 1953, (Bayrak, R., Tatli H., 2016). Dimana menurut Malmquist index nilai yang (>1) menunjukkan meningkatkan efisiensi dan nilai $(<1)$ menunjukkan penurunan efisiensi untuk istilah terkait. Tapi, nilainya sama dengan $1(=1)$ berarti tidak ada perubahan efisiensi. pengukuran 
tingkat produktivitas menggunakan analisis statistik deskriptif. Setelah itu menghitung nilai rata-rata untuk membandingkan industri yang satu dengan yang lainnya dalam sentra. Statistik deskriptif yang digunakan dalam penelitian ini yaitu perhitungan mean dan distribusi frekuensi.

\section{Variabel Penelitian}

Variabel penelitian adalah sesuatu yang digunakan oleh peneliti sebagai objek untuk dipelajari. Peneliti dapat memperoleh data yang dibutuhkan serta dapat menarik kesimpulan dari penelitian yang telah dilakukan. Variabel penelitian adalah sifat suatu benda yang akan dipelajari dalam penelitian. Variabel penelitian merupakan segala sesuatu yang membuat peneliti segera ingin mempelajarinya dan menarik kesimpulan dari variabel-variabel tersebut. Variabel penelitian yang digunakan dalam penelitian ini sebagai berikut.

Tabel 1. Variabel Penelitian

\begin{tabular}{ll}
\hline Variabel & Definisi \\
\hline Nilai Total Output & $\begin{array}{l}\text { Nilai penjualan hasil produksi yang } \\
\text { dihasilkan dalam satu tahun (Rp) }\end{array}$ \\
\hline Nilai pekerja & Upah pekerja dalam satu tahun (Rp) \\
\hline Nilai bahan baku & Biaya bahan baku dalam satu tahun (Rp) \\
\hline Nilai modal & $\begin{array}{l}\text { Biaya penyusutan dan perawatan dalam } \\
\text { satu tahun (Rp) }\end{array}$ \\
\hline
\end{tabular}

Penjabaran dari input dan ouput industri mebel dijelaskan sebagai berikut.

1. Modal

Menurut Rosyidi (2004), modal mencakup uang yang tersedia di dalam perusahaan untuk membeli mesin-mesin serta faktor produksi lainnya. Maka pada penelitian ini modal yang dihitung merupakan biaya untuk membeli peralatan (gergaji, catem, palu, amplas) dan mesin-mesin pengolah kayu (mesin profil, gerinda, circle saw) beserta biaya perawatan peralatan tersebut yang dihitung dalam kurun waktu 1 tahun (Rp/Tahun).

2. Tenaga Kerja

Tenaga kerja merujuk pada kemampuan manusiawi yang dapat disumbangkan untuk memungkinkan dilakukannya produksi barang-barang dan jasa-jasa, (Rosyidi, 2004). Maka untuk mengganti kemampuan tersebut perusahaan diwajibkan memberikan upah atau biaya tenaga kerja yang biasanya dibayarkan setiap bulan. Pada penelitian ini biaya tenaga kerja dihitung dari akumulasi industri mengelurakan upah terhadap seluruh pekerja selama 1 tahun (Rp/Tahun).

3. Bahan Baku

Bahan baku merupakan jumlah bahan yang diperlukan untuk melaksanakan proses produksi dalam jangka waktu tertentu (Siswanta, 2011). Bahan baku yan digunakan yang utama adalah kayu multiplex, pinus dan jati serta bahan baku pendukung seperti lem, paku, plitur dan lain sebagainya. Pengeluaran industri terhadap belanja bahan baku ini akan diakumulasikan dalam 1 tahun (Rp/Tahun).

\section{HASIL DAN PEMBAHASAN}

\section{Gambaran Umum}

Sentra Industri Mebel Tunjungsekar berlokasi di sepanjang koridor jalan Ikan Piranha Atas, Kelurahan Tunjungsekar, Kecamatan Lowokwaru, Kota Malang. Kelurahan Tunjungsekar secara geografi memiliki luas wilayah sebesar $187 \mathrm{~km}^{2}$. Lokasi kawasan Sentra Industri Mebel Tunjungsekar ditunjukkan pada Gambar 1.

Sentra mebel ini berdiri sejak lama sekitar tahun 1950- an, hingga pada tahun 1990-an pengerajin sudah terlepas dari pengepul dan berdiri sendiri mendirikan usaha mebelnya. Para produsen mebel yang telah membuka usahanya sejak lama di Tunjungsekar tergabung dalam paguyuban yang bernama "Sido Rukun" pada tahun 1990 berawal adanya kerja sama dengan Fakultas Ekonomi dan Bisnis UB. Kini paguyuan tersebut beranggotakan 30 industri, seluruh industri tersebut menjadi responden penelitian ini.

Bahan baku yang digunakan untuk menghasilkan mebel yaitu kayu multiplex yang didapatkan dari suplier terdekat yaitu Dunia Mebel dan bahan baku penunjang seperti paku, lem dan alat-alat seperti bor didapatkan juga dari suplier terdekat yaitu Sahabat Baru. Kayu-kayu besar seperti pinus dan jati didapatkan dari suplier yang berada di Karangploso dengan. Peralatan yang digunakan antar industri di sentra industri mebel Tunjungsekar cenderung sama atau sejenis yaitu antara lain: tatah, palu, pasrahan, catut, kompressor bor, mesin gosok, circle saw, sending dan mesin profil. Tidak ada kerja sama penggunaan alat, produsen menggunakan alat masing-masing milik pribadi. 


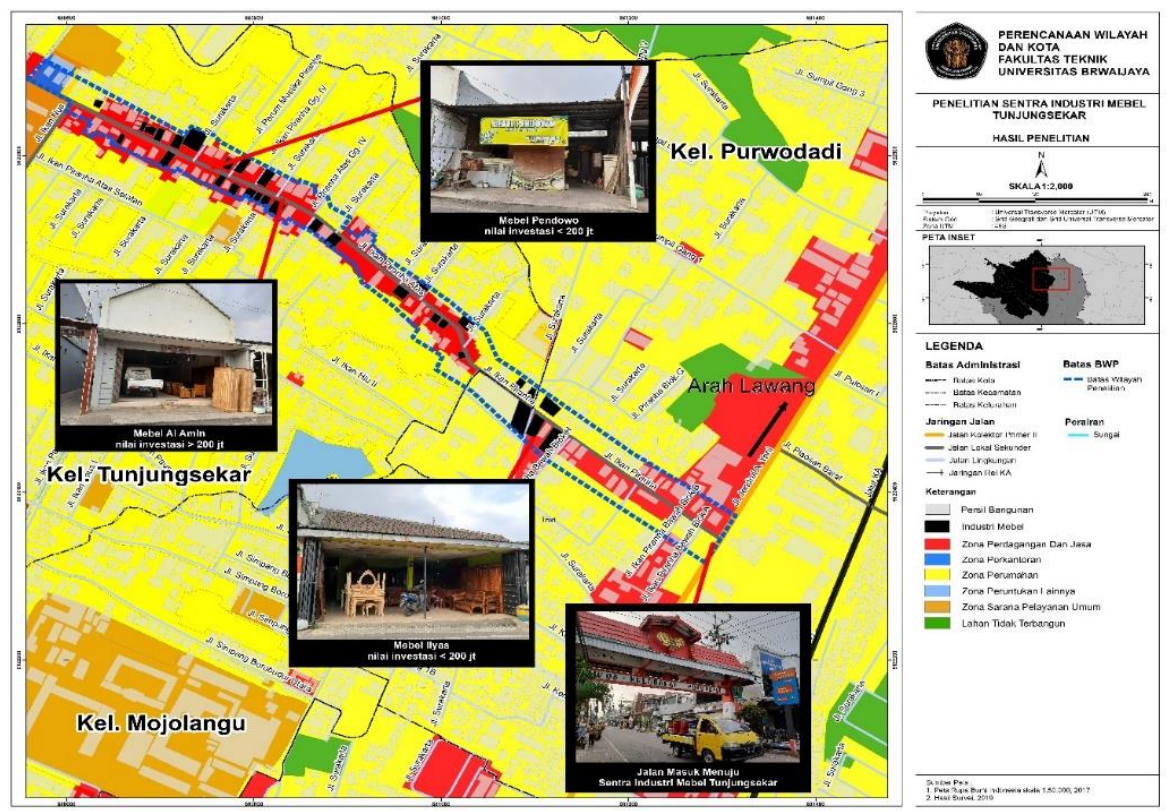

Gambar 1. Photo Mapping Sentra Industri Mebel Tunjungsekar

Mebel yang dihasilkan berbagai macam sesuai pesanan konsumen seperti dipan, rak-rak an, almari, meja, kursi, kitchen set dan lain sebagainya. Hampir $70 \%$ hasil mebel di Tunjungsekar ini mampu menembus pasar regional atau melayani wilayah Jawa Timur.

Alur proses produksi mebel pada sentra industri mebel Tunjungsekar dilakukan secara mandiri oleh masing-masing unit usaha. Proses produksi mebel dimulai dengan pembelian bahan baku kayu hingga pemasaran pada Gambar 2.

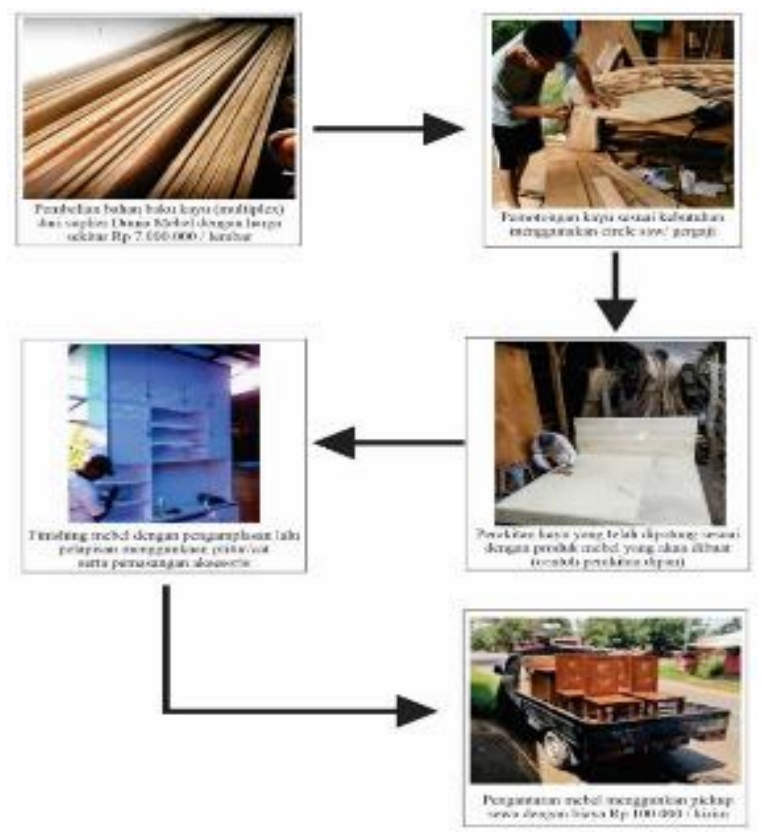

Gambar 2. Proses Produksi Hingga Pemasaran Mebel Tunjungsekar

\section{Analisis Produktivitas Sentra Industri Mebel Tunjungsekar}

Dalam pendetailan pembahasan, maka industri dikelompokkan berdasarkan nilai investasinya. Nilai investasi adalah nilai tanah dan bangunan tidak termasuk tempat tinggal, sarana dan prasarana, tidak termasuk modal kerja yang digunakan untuk melakukan kegiatan industri (Permen Perindustrian No. 64 tahun 2016). Menurut surat edaran Bank Indonesia kepada seluruh bank umum di Indonesia No.3/9/Bkr, tanggal 17 Mei 2001, industri kecil memiliki nilai aset/ investasi dengan nilai maksimal $\mathrm{Rp}$ 200.000.000, maka pada pembahasan penelitian ini industri kecil dikategorisasi menjadi 2 berdasarkan nilai investasinya, yaitu industri yang memiliki nilai investasi $\leq$ Rp 200.000.000 dan industri dengan nilai investasi $>$ Rp 200.000.000. Pada ke-30 industri mebel yang ada di Tunjungsekar didapatkan data nilai inevstasi sebagai berikut.

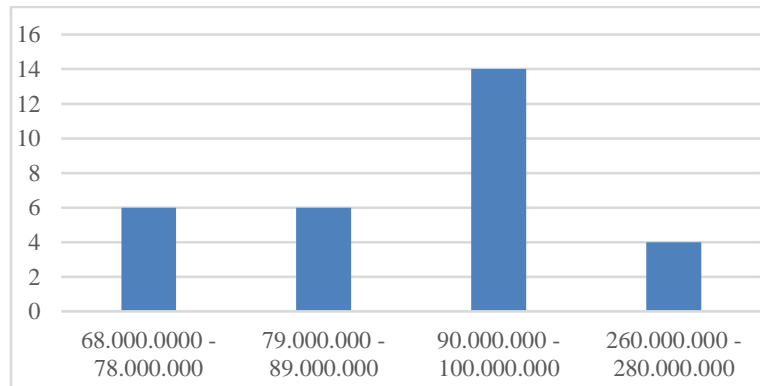

Gambar 3. Klasifikasi Nilai Investasi Mebel Tunjungsekar 


\section{Nilai Input}

\section{a) Tenaga Kerja}

Tenaga kerja yang diserap oleh industri mebel Tunjungsekar berasal dari keluarga sendiri atau masyarakat sekitar. Tenaga kerja ini memiliki kemampuan dari bakat turun temurun, seluruh tenaga kerja ialah laki-laki.

Tabel 2. Nilai Tenaga Kerja

\begin{tabular}{lc}
\hline \multicolumn{3}{c}{ Industri $\leq$ Rp 200 juta } \\
\hline Biaya Tenaga Kerja (Rp/Thn) & Jumlah Industri (unit) \\
\hline $7.800 .000-<21.600 .000$ & 10 \\
\hline $21.600 .000-<35.400 .000$ & 4 \\
\hline $35.400 .000-<49.200 .000$ & 5 \\
\hline $49.200 .000-<63.000 .000$ & 4 \\
\hline $63.000 .000-76.800 .000$ & 3 \\
\hline \multicolumn{1}{c}{ Industri $>$ Rp 200 juta } \\
\hline Biaya Tenaga Kerja (Rp/Thn) & Jumlah Industri (unit) \\
\hline $96.000 .000-<112.800 .000$ & 2 \\
\hline $112.800 .000-129.600 .000$ & 2 \\
\hline
\end{tabular}

Berdasarkan Tabel 2 industri dengan investasi $\leq 200$ juta rata-rata mmeiliki pekerja sebanyak 4 orang dengan rata-rata gaji perbulan Rp 750.000/orang. Dengan jam kerja rata-rata 6 jam dalam sehari dan 1 jam waktu untuk istirahat sehingga pekerja menghabiskan waktu 7 jam di lokasi bekerja. Namun juga sering terjadi para pekerja hanya bekerja ketika terdapat pesanan atau tidak setiap harinya selalu berproduksi. Sebanyak $80 \%$ tenaga kerja yang ada merupakan masyarakat sekitar Tunjungsekar baik masih keluarga, kerabat hingga tetangga dengan rentan usia 40 - 60 tahun.

Pada industri dengan nilai investasi $>200$ juta, memiliki rata-rata jumlah tenaga kerja sebanyak 9 orang dengan gaji perbulan rata-rata sebesar Rp 950.000 / orang. Pada industri ini dapat membayar pekerjanya dengan upah yang lebih besar dikarenakan terkadang pekerjanya harus menyelesaikan produksi mebel di luar rumah produksi seperti perakitan mebel pada ruangruang kantor atau pada apartemen

\section{b) Bahan Baku}

Bahan baku ialah bahan utama yang digunakan dalam produksi suatu industri. Bahan baku utama kayu, bahan baku pendukung seperti lem, plitur, paku dan lain sebagainya dan sumber daya energi berupa listrik, karena pengolahan mebel menggunakan mesin-mesin yang sumber daya nya yaitu listrik.
Tabel 3. Nilai Bahan Baku

\begin{tabular}{lc}
\hline \multicolumn{2}{c}{ Industri $\leq$ Rp 200 juta } \\
\hline Biaya Modal (Rp/Thn) & Jumlah Industri (unit) \\
\hline $96.886 .000-<119.578 .400$ & 5 \\
\hline $119.578 .400-<142.270 .800$ & 5 \\
\hline $142.270 .800-<164.963 .200$ & 3 \\
\hline $164.963 .200-<187.655 .600$ & 4 \\
\hline $187.655 .600-210.348 .000$ & 9 \\
\hline \multicolumn{1}{c}{ Industri $>$ Rp 200 juta } \\
\hline Biaya Modal (Rp/Thn) & Jumlah Industri (unit) \\
\hline $234.000 .000-<267.335 .000$ & 3 \\
\hline $267.335 .000-<300.670 .000$ & 1 \\
\hline
\end{tabular}

Industri dengan nilai investasi $\leq$ Rp 200 juta sebagian besar didominasi dengan industri yang mengeluarkan biaya bahan baku sejumlah 187.655.600 - 210.348.000. Namun masih terjadi ketimpangan yang cukup jauh pengeluaran biaya bahan baku antar industri dikarenakan terdapat perbedaan bahan baku yang digunakan, industri yang pengeluarannya lebih besar telah menggunakan kayu pinus, dan industri dengan pengeluaran di bawahnya berproduksi menggunakan kayu multiplex.

Industri dengan nilai investasi > 200 juta memiliki pengeluaran bahan baku lebih besar dibandingkan kelas investasi di bawahnya karena kuantitas dan kualitas yang dihasilkanpun berbeda, kayu jati dan pinus juga banyak digunakan sebagai bahan baku selain multiplex, selain itu industri pada investasi ini memiliki pesanan dalam jumlah besar atau dengan sistem borongan seperti mengerjakan furnitur 1 set kamar pada apartemen, furnitur perumahan atau juga perkantoran.

\section{c) Modal}

Modal ialah biaya tetap yang digunakan untuk produksi mebel. Pelaku industri mendapatkan modal dari kekayaan sendiri.

Tabel 4. Nilai Modal

\section{Industri $\leq \mathbf{R p} 200$ juta}

Biaya Modal (Rp/Thn) Jumlah Industri (unit)

\begin{tabular}{lc}
\hline $14.725 .900-<15.580 .720$ & 4 \\
\hline $15.580 .720-<16.435 .540$ & 2 \\
\hline $16.435 .540-<17.290 .360$ & 3 \\
\hline $17.290 .360-<18.145 .180$ & 7 \\
\hline $18.145 .180-19.000 .000$ & 10 \\
\hline \multicolumn{2}{c}{ Industri $>$ Rp 200 juta } \\
\hline Biaya Modal (Rp/Thn) & Jumlah Industri (unit) \\
\hline $33.750 .000-<37.125 .000$ & 2 \\
\hline
\end{tabular}


Industri $\leq$ Rp 200 juta

Biaya Modal (Rp/Thn)

Jumlah Industri (unit)

$37.125 .000-<40.500 .000$

Industri mebel dengan nilai investasi $\leq \mathrm{Rp}$ 200.000.000 memiliki rata-rata biaya untuk modal pada industri ini $\mathrm{Rp}$ 17.445.254. Sedangkan industri dengan nilai investasi > Rp 200.000.000 rata-rata mengeluarkan biaya modal sebesar $\mathrm{Rp}$ 36.762.500. Modal yang dikeluarkan untuk usaha memang tidak terpaut terlalu jauh antara 2 klasifikasi industri dikarenakan peralatan utama yang digunakan cenderung sama atau sejenis hanya berbeda dalam jumlah dan kualitasnya. Untuk penggunaan mesin kayu modern seperti penggunaan mesin laser dan lain sebagainya masih belum digunakan di sentra industri mebel Tunjungsekar.

\section{Nilai Output}

Output adalah jumlah mebel yang terjual dalam setiap tahun dan disajikan dalam nilai rupiah. Output industri bergantung pada jumlah bahan baku yang digunakan, bahan baku yang digunakan juga dipengaruhi oleh jumlah pemesanan. Rata-rata harga penjualan mebel di Tunjungsekar yaitu sebesar Rp 3.800.000/unit.

Tabel 5. Nilai Pendapatan

\begin{tabular}{lc}
\hline \multicolumn{2}{c}{ Industri $\leq$ Rp 200 juta } \\
\hline Pendapatan (Rp/Thn) & $\begin{array}{c}\text { Jumlah Industri } \\
\text { (unit) }\end{array}$ \\
\hline $144.400 .000-<199.120 .000$ & 7 \\
\hline $199.120 .000-<253.840 .000$ & 4 \\
\hline $253.840 .000-<308.560 .000$ & 6 \\
\hline $308.560 .000-<363.280 .000$ & 3 \\
\hline $363.280 .000-418.000 .000$ & 6 \\
\hline \multicolumn{1}{c}{ Industri $>$ Rp 200 juta } \\
\hline Pendapatan (Rp/Thn) & Jumlah Industri \\
\hline 543.400.000- $<644.100 .000$ & 2 \\
\hline 644.100.000 - <744.800.000 & 2 \\
\hline
\end{tabular}

Industri dengan nilai investasi $\leq \mathrm{Rp}$ 200.000.000 rata-rata jumlah unit mebel yang dihasilkan mencapai 72 unit/ tahun dengan paling banyak 110 unit / tahun dan paling sedikit 38 unit/tahunnya. Produk yang dihasilkan cenderung untuk memenuhi pelanggan satuan.

Industri dengan nilai investasi $>\mathrm{Rp}$ 200.000.000, memiliki pendapatan rata-rata sebesar Rp 604.200.000, rata-rata produk yang dihasilkan 166 unit/tahun dengan produksi paling banyak mencapai 196 unit / tahun dan paling sedikit 143 unit/ tahun. Produk yang dihasilkan pada 4 industri ini selain bagi konsumen satuan juga sering melayani konsumen besar atau borongan seperti untuk mengisi kantor, kamar hotel, apartemen dan lain sebagainya.

\section{Produktivitas Industri}

Tabel 6 menunjukkan nilai produktivitas ke-30 industri memiliki nilai di atas 1,0 dengan nilai tertinggi 1,58 dan terendah 1,14 . Menurut Malmquist Index Productivity nilai produktivitas yang menunjukkan diatas 1,0 artinya industri tersebut telah efektif dalam memproduksi mebel dan efisien dalam memanfaatkan sumber daya.

Tabel 6. Produktivitas Industri

\begin{tabular}{|c|c|c|c|}
\hline $\begin{array}{c}\text { Klasifikasi } \\
\text { Investasi }\end{array}$ & No & Nama Toko & $\begin{array}{c}\text { Nilai } \\
\text { Produktivitas }\end{array}$ \\
\hline \multirow{26}{*}{$\begin{array}{c}\leq \mathrm{Rp} \\
200.000 .000\end{array}$} & 1 & Bayu & 1,30 \\
\hline & 2 & Manggal & 1,16 \\
\hline & 3 & Prambos & 1,19 \\
\hline & 4 & Dwi Jaya & 1,31 \\
\hline & 5 & Oki & 1,18 \\
\hline & 6 & Sulastri & 1,22 \\
\hline & 7 & Wahyu & 1,29 \\
\hline & 8 & Win Mebel & 1,15 \\
\hline & 9 & Wisnu Jaya & 1,30 \\
\hline & 10 & Rafi Interior & 1,20 \\
\hline & 11 & Erlangga Onyx & 1,22 \\
\hline & 12 & Karomah & 1,33 \\
\hline & 13 & Mebel 6 & 1,28 \\
\hline & 14 & Pendowo & 1,27 \\
\hline & 15 & Tunggal & 1,25 \\
\hline & 16 & Mia & 1,19 \\
\hline & 17 & Narsip & 1,14 \\
\hline & 18 & Yanto & 1,33 \\
\hline & 19 & Fuji Lumayan & 1,32 \\
\hline & 20 & Kusuma Jaya & 1,38 \\
\hline & 21 & Salis Jaya & 1,32 \\
\hline & 22 & Prambors & 1,36 \\
\hline & 23 & Arofah & 1,38 \\
\hline & 24 & Usaha Jati & 1,38 \\
\hline & 25 & Ilyas & 1,37 \\
\hline & 26 & Moch Toyib & 1,37 \\
\hline \multirow{4}{*}{$\begin{array}{c}>\mathrm{Rp} \\
200.000 .000\end{array}$} & 27 & Barokah & 1,58 \\
\hline & 28 & Srikandi & 1,49 \\
\hline & 29 & Al-Amin & 1,51 \\
\hline & 30 & Putra Jati Bersama & 1,56 \\
\hline
\end{tabular}

Seluruh nilai produktivitas industri memiliki nilai mendekati 1 atau tidak terpaut lebihbanyak dari nilai 1, sehingga kondisi ini masih imbang antara pengeluaran total dengan pemasukan total atau kondisi ini belum benarbenar ideal karena masih terdapat beberapa permasalahan yang terjadi antara lain:

1. Penghasilan yang didapatkan masih impas antara biaya produksi dengan penghasilan yang didapat, atau laba yang didapatkan masih sedikit. 
2. Tingginya biaya input seperti adanya biaya pengiriman bahan baku terlebih harga bahan baku juga semakin tinggi dan belum adanya kerja sama antar produsen mebel dalam pengadaan bahan baku, serta belum ada kerja sama dalam penggunaan peralatan dan mesin dengan teknologi yang canggih untuk memaksimalkan produksi mebel.

3. Jumlah output (permintaan) yang tidak stabil sebaiknya juga didorong dengan adanya kerja sama dalam pemasaran seperti pembelian barang setengah jadi antar perusahaan, sehingga output yang dihasilkan pada tiap-tiap industri tidak terjadi ketimpangan.

4. Kondisi tidak ideal ini juga terlihat pada komponen input yaitu upah tenaga kerja, dimana upah tenaga kerja yang dibayarkan rata-rata hanya $\mathrm{Rp} 400.000$ - Rp 1.000 .000 per-bulan per-orang, jumlah ini masih sekitar 30\% dari UMK Kota Malang pada tahun 2020 sejumlah Rp 2.895.502.

5. Aglomerasi yang terjadi masih sebatas kedekatan secara lokasi, namun belum banyak kerja sama dalam jaringan yang dilakukan oleh masing-masing pemilik industri di Sentra Industri Mebel Tunjungsekar.

Untuk melihat daya saing industri yang satu dengan yang lainnya dalam klaster maka dengan membandingkan nilai produktivitas masingmasing industri dengan nilai produktivitas ratarata. Mean atau nilai rata-rata adalah nilai representatif untuk mewakili sekumpulan data. Berikut akan dibahas rata-rata hitung atau mean. Mean adalah hasil bagi jumlah data dengan banyak data. Adapun perhitungan mean sebagai berikut:

$$
\bar{x}=\frac{\sum_{i=1}^{n} x_{i}}{n}
$$

Keterangan:

$\bar{x}=$ mean

$\sum_{i=1}^{n} x_{i}=$ jumlah data

$\mathrm{n}=$ banyak data

Nilai mean yang didapatkan adalah adalah 1,31 maka dengan mean ini sebagai pengukur posisi produktivitas industri yang satu dengan yang lainnya sebagai berikut.

Tabel 7. Distribusi Nilai Produktivitas

\begin{tabular}{cc}
\hline Nilai Produktivitas & Jumlah Industri (unit) \\
\hline$<\mathbf{1 , 3 1}$ & 15 \\
\hline $\mathbf{1 , 3 1}$ & 1 \\
\hline $\mathbf{1 , 3 1}$ & 14 \\
\hline
\end{tabular}

Berdasarkan Tabel 7 dapat ditunjukkan bahwa terdapat 15 unit industri yang produktivitasnya dibawah rata-rata dan 14 industri yang memiliki produktivitas di atas rata-rata industri mebel lainnya. Banyaknya industri yang memiliki produktivitas di bawah rata-rata dari produktivitas industri lain dikarenakan harga peralatan dan mesin serta bahan baku yang digunakan semakin tinggi namun kondisi ini tidak diimbangi dengan jumlah pesanan yang tinggi pula. Berikut ini adalah diagram dari biaya modal dan bahan baku yang dibandingkan dengan total pendapatan dalam 1 tahun.

Sebanyak 15 industri dengan produktivitas yang di bawah rata-rata industri lainnya disebabkan industri tersebut harus mengeluarkan biaya modal dan bahan baku yang tinggi namun tidak diimbangi dengan penjualan yang tinggi pula, atau berbanding terbalik dengan pendapatan yang didapat. Selian itu perbedaan nilai produktivitas juga dipengaruhi faktor lain seperti pada industri dengan nilai investasi $>\mathrm{Rp}$ 200.000.000 ini telah banyak melayani konsumen besar atau sistem borongan seperti pengerjaan kantor, hotel, apartemen, cafe , sekolah dan lain sebagainya.

Denganmemanfaatkan kedekatan lokasi dan mengintegrasikan dengan faktor-faktor ytang berpengaruh dapat meningkatkan nilai produktivitas industri tersebut. Faktor-faktor yang mempengaruhi perkembangan sentra dalam antara lain:

a. Faktor lokasi mempengaruhi perkembangan klaster dalam terkonsentrasinya munculnya industri, peningkatan inovasi dan menguatnya kerjasama

b. faktor infrastruktur mempengaruhi perkembangan sentra dalam mendukung perkembangan industri yang terkonsentrasi di dalam klaster,

c. Faktor sarana mempengaruhi perkembangan sentra dalam hal peningkatan kerjasama,

d. Faktor aksesibilitas juga mempengaruhi perkembangan sentra dalam meningkatnya kerjasama.

\section{KESIMPULAN}

Berdasarkan hasil analisa dapat disimpulkan bahwa nilai produktivitas ke-30 industri di Sentra Industri Mebel Tunjungsekar rata-rata sebesar 1,31 dengan nilai terendah 1,14 dan tertinggi sebesar 1,58. Hasil tersebut memperlihatkan bahwa seluruh industri memiliki nilai produktivitas tidak jauh di atas 1,0 sehingga kondisi tersebut belum mencapai kondisi yang 
ideal atau perusahaan yang ada hanya impas antara biaya produksi dengan penghasilan yang didapat.

Di samping itu, ke-15 industri yang memiliki nilai produktivitas di bawah rata-rata $(1,31)$ yang seluruhnya merupakan industri dengan nilai investasi < Rp 200 juta. Kondisi belum ideal ini juga terlihat pada faktor input biaya tenaga kerja, dimana upah tenaga kerja yang dibayarkan dibayarkan rata-rata hanya $\mathrm{Rp} 400.000$ - Rp 1.000.000 per-bulan per-orang, jumlah ini hanya sekitar $30 \%$ dari UMK Kota Malang pada tahun 2020 sejumlah Rp 2.895.502. Faktor lain penyebab kondisi yang kurang ideal tersebut dikarenakan biaya bahan baku serta modal yang dikeluarkan terlalu tinggi, namun tidak diimbangi dengan jumlah pemesanan produk mebel dengan jumlah yang banyak, pesanan yang di dapat hanya berupa 1 atau 2 produk mebel berbeda dengan industri dengan nilai investasi > Rp 200 juta, dimana pesanan mebel sudah dalam jumlah besar seperti untuk pengisian apartemen, kantor, cafe dan lain sebagainya. Padahal, dari adanya kedekatan lokasi yang tercipta manfaat yang hadir seperti adanya pembelian barang setengah jadi antar produsen, peningkatan kredibilitas industri serta adanya kerja sama dalam pengadaan bahan baku hingga pemasaran.

\section{DAFTAR PUSTAKA}

Blocher, E. J., Stout, D. E., Juras, P. E., \& Smith, S. (2019). Cost Management (A Strategic Emphasis) 8e. McGraw-Hill Education.

Badan Pusat Statistik. (2020). Kota Malang Dalam Angka. Jakarta: BPS.

Bayrak, R., Tatli H. (2016). Short and Long Term Analysis of Some factors Affecting Youth Unemployment in Turkey. Theoretical and Applied Economics. Vol. I 3 (3): 229242.

Cahyanti, M. M., \& Anjaningrum, W. D. (2017). Faktor-Faktor Yang Mempengaruhi Perkembangan Usaha Kecil Sektor Industri Pengolahan Di Kota Malang. Jurnal Jibeka Vol. 11 No.2. Hal: 73 79.

Djamhari, Choirul. (2006). Faktor-faktor yang Mempengaruhi Perkembangan Sentra UKM Menjadi Klaster Dinamis. Jurnal Penelitian Infokop Nomor 29 Tahun XXII.

Dolling, N. (2018). Faktor-Faktor yang Mempengaruhi Keberhasilan Usaha Mikro Kecil Berbasis Ekonomi Kreatif di Kota Makassar. Makassar: Universitas Negeri Makassar.
Fatmawati, A. (2008). Pengembangan Industri Mebel Kota Malang (Studi Kasus: Kelurahan Tunjungsekar dan Kelurahan Purwodadi. Skripsi. Tidak dipublikasikan. Malang: Universitas Brawijaya.

Felzensztein, C., Huemer, L., \& Gimmon, E. (2010). The Effect of Co-location on Marketing Externalities in the Salmon-Farming Industry. Journal of Business \& Industrial Marketing 25/1, 73-82.

Fithri, P., \& Sari, R. Y. (2015). Analisis Pengukuran Produktivitas Perusahaan Alsintan CV. Cherry Sarana Agro. Jurnal Optimasi Sistem Industri Vol. 14 no. $1,138-155$.

Indriartiningtias, R., Subagyo, \& Hartono, B. (2017). Knowledge Creation pada Industri Kecil dan Menengah: Dalam Tinjauan Kajian Pustaka Secara Sistematis. Jurnal Ilmiah Teknik Industri, 142 - 149.

Laporan Kinerja Kementrian Perindustrian Republik Indonesia tahun 2019.

Ma. J., Wang. J., and Szmedra. P. (2019). Economic Efficiency and Its Influencing Factors on Urban Agglomeration-An Analysis Based on China's Top 10 Urban Agglomerations. Journal Sustainable Urban and Rural Development Vo. 11. Issue. 19.

N. S. Eminawati et al. (2020). Faktor-Faktor Spasial Yang Mempengaruhi Perkembangan Klaster Industri (Studi Kasus: Industri Gitar Di Desa Mancasan, Desa Ngrombo Dan Desa Pondok, Kabupaten Sukoharjo). Jurnal Pembangunan Wilayah dan Perencanaan Partisipatif, Vol. 15(2) 2020, 139-151.

Peraturan Menteri Perindustrian Nomor 64 Tahun 2016.

Prianata, Rahadian. (2014). Pengaruh JumlahTenaga Kerja, Bahan Baku dan Teknologi terhadap Produksi Industri Furniture di Kota Denpasar. Jurnal Ekonomi Pembangunan Vol. 3 No. 1.

Rosyidi, Suherman. (2004). Pengantar Teori Ekonomi: Pendekatan Kepada Teori Ekonomi Mikro dan Makro (Edisi Revisi). Jakarta: PT Raja Grafindo Persada.

Siswanta, Lilik. 2011. Analisis Faktor Faktor Yang Mempengaruhi Pendapatan Perajin Genteng (Studi kasus pada industri kerajinan genteng di ceper Klaten ). Akmenika UPY. Vol. 7. Hal: 74-88. 
TINGKAT PRODUKTIVITAS PADA AGLOMERASI INDUSTRI (STUDI KASUS : SENTRA INDUSTRI MEBEL TUNJUNGSEKAR)

Suryandari, Elvida. Y. (2008). Analisis Permintaan Kayu Bulat Industri Pengolahan Kayu (Log Demand Analysis On Forest Product Industry). Jurnal Penelitian Sosial dan Ekonomi Vol. 5 No.1. 